\title{
Bromodomain-Containing Protein 4
}

National Cancer Institute

\section{Source}

National Cancer Institute. Bromodomain-Containing Protein 4. NCI Thesaurus. Code C92704.

Bromodomain-containing protein $4(1362 \mathrm{aa}, \sim 152 \mathrm{kDa})$ is encoded by the human BRD4 gene. This protein plays a role in the mitotic process. 